\title{
TIME IN SENECA: PAST, PRESENT, FUTURE
}

Respice celeritatem rapidissimi temporis... $($ Ep. 99, 7)

Seneca frequently reflects on the passing of time and the brevity of life. Numerous passages are found in his writings that reveal his sensitivity to time's velocity. His concern with time - its role, its place, its significance in man's life - is apparent throughout his philosophic works. His aim is to teach his fellow-men how to properly regard time (past, present, future) and, by so doing, how to live well and progress toward virtue and wisdom.

Living in an era of secularity, with urban over-crowding and a plethora of bureaucracy, Seneca, like many a modern two thousand years later, was afflicted by Angst, taedium, restlessness, an empty sense of malaise. Particularly as he grew older, he became ever more acutely aware of time and its inexorable passing. He was attracted to Vergil's lines,

Optima quaeque dies miseris mortalibus aeui prima fugit... ${ }^{1}$

And, like Milton, Seneca potently sensed that his «hasting days fly on with full career» ${ }^{2}$. Thus he left a body of testimony - in many of his writings - that certified his almost existential sense of crisis when he confronted the fact of time's intrepid and precipitate transit. He writes, with urgency and passion:

Mors me sequitur, fugit uita; aduersus haec me doce aliquid ${ }^{3}$.

1 Georgics III 66-67; quoted twice by Seneca, in Ep. 108, 24 and in De Breu. Vit. 9,2.

2 See John Milton's sonnet, «How Soon Hath Time, the Subtle Thief of Youth" (1631), line 3 .

${ }^{3}$ Ep. 49,9. Hereafter, quoted passages from Senecan texts will be identified, within parentheses, in the body of this paper. Throughout, we have used the following stand- 
Everywhere in his prose Seneca is aware that we are «born for the briefest time $)^{4}$, and he frequently explores the crisis confronting an individual who comes to recognize that he has wasted his life. Seneca will even go so far upon ocassion as to mock himself as the poor manager and defective businessman of temporary affairs ${ }^{5}$.

In short, time is a powerful subject for Seneca, one he cannot evade, and one he resorts to repeatedly. Often, he pauses to analyze the very nature and partitioning of time. As a part of this analysis, Seneca commences by reminding us of an important fact: man alone upon this planet is fully conscious of his place in time.

Ferae pericula quae uident fugiunt, cum effugere, securae sunt: nos et uenturo torquemur et praeterito.

(Ep. 5,9)

A telling point: man's grandeur, his broad comprehension of the human condition, is simultaneously his bane. Robert Burns has poignantly dramatized man's plight on this score, in the finale of one of his poems. Although Burns, after accidentally overturning its nest with his plow, commiserates with the mouse thus rendered homeless, he nonetheless at the poem's close attains a stroke of painful insight, recognizing that man alone suffers from a three-fold satchel of troubles. As he tells the mouse,

\author{
Still thou art blest compar'd wi' me! \\ The present only toucheth thee: \\ But och! I backward cast my e'e \\ On prospects drear! \\ An' forward tho' I canna see, \\ I guess an' fear! ${ }^{\circ}$
}

ard volumes, when referring to Senecan writings: Ad Lucilius Epistulae Morales, ed. L. D. Reynolds, 2 vols., Oxford 1965; Dialogorum libri duodecim, ed. L. D. Reynolds, Oxford 1977; Naturales Quaestiones, ed. Thomas H. Corcoran, 2 vols., Cambridge, Mass. \& London 1971; and Tragoediae, ed. Ioannes Carolus Giardina, 2 vols., Bologna 1966.

4 Ad Marc. 20,1.

5 Vid. his presentation of himself in Ep. 1 of the Epistulae Morales to Lucilius as a comic butt, the poor businessman and banker of time. Note De Cons. Sap. 17,2: ...nemo risum praebuit qui ex se cepit, and consult Anna Lydia Motto and John R. Clark, "Senecan Irony», $C B 45,1968$, pp. 6-7, 9-11.

- Robert Burns, To A Mouse, lines 43-48, in English Romantic Poetry and Prose, ed. Russell Noyes, New York 1956, p. 149. Seneca's ideas on past, present, and future, are a conventional Stoic distinction stemming back to Aristotle; Alberto Grilli, «L'Uomo e il Tempo", in Seneca: Letture critiche, ed. Alfonso Traina, Milan 1976, pp. 57-67, stresses that such ideas in Seneca derive particularly from Aristippus, Panaetius, and 
Seneca, to be sure, remarks very well this tri-partite division of man's life-in-time:

In tria tempora uita diuiditur: quod fuit, quod est, quod futurum est. Ex iis quod agimus breue est, quod acturi sumus dubium, quod egimus certum; hoc est enim in quod fortuna ius perdidit... Hoc amittunt occupati; nec enim illis uacat praeterita respicere...

(De Breu. Vit. 10,2)

"The present consists of only one day at a time, and, in fact, only a minute at a time.... ${ }^{8}$, and is therefore subject to insecurity, volatility, changeableness; whereas the past is solid, secure - the stuff of meditation and recollection, capable of being recalled at will. The occupati, or the engrossed, are devoted, on the contrary, to the present:

...occupatorum animi, uelut sub iugo sint, flectere se ac respicere non possunt. Abit igitur uita eorum in profundum et ut nihil prodest, licet quantumlibet ingeras, si no subest quod excipiat ac seruet, sic, nihil refert quantum temporis detur, si non est ubi subsidat, per quassos foratosque animos transmittitur. Praesens tempus breuissimum est, adeo quidem ut quibusdam nullum uideatur; in cursu enim semper est, fluit et praecipitatur; ante desinit esse quam uenit...

(De Breu. Vit. 10,5-6)

The images here are striking. The advocate of "now» cannot turn about; he is compelled to face in a single direction. The implication is that such individuals are in Hades, caught in a mandatory shadow-world like the fifty Danaids with their leaky vessels or the Emperor Claudius with

\footnotetext{
Plutarch. Popular, non-philosophic ideas about time from the Homeric and Archaic periods are traced by R. B. Onians, The Origins of European Thought about The Body, The Mind, The Soul, The World, Time, and Fate, Cambridge 1951, esp. Pt. III, pp. 303466. The traditional philosophic concepts about Time include Plato's belief in time as a steady flow or motion (Timaeus, esp. 37c-38c); the more scientific and influential treatment is Aristotle's (Physics IV 11-14), discriminating between past, present, and future, and focusing on the present as a species of mathematical point. Aristotle treats time as the measurement of motion. See Catherine Rau, "Theories of Time in Ancient Philosophy", Philosophical Review 62, 1953, pp. 514-25, and particularly John F. Callahan, Four Views of Time in Ancient Philosophy. Cambridge, Mass. 1948, esp. Chh. 1 (Plato), and 2 (Aristotle).

7 Conventionally, the occupati are those who are busy, employed, without time to spare. In Seneca, however, the term occupati is used pejoratively. Seneca's paradoxical treatment of the occupati implies that they waste time and, in terms of serious activities, have virtually nothing to do at all. Vid. De Breu. Vit. 7,3; 12,1-2; De Tranq. An. 12,3.

8 De Breu. Vit. 10,4.
} 
his perforated dice-box in the Underworld as depicted in Seneca's Apocolocyntosis 14.

And the Underworld - a land of fixity and bleak permanence - is aptly used to portray the realm of Time. Its denizens are driven, anxious, wraithlike, furtive, and dissatisfied. Seneca explains in one passage that all men are anxious about what is to be, and consequently unhappy with their present lot.

Praecipitat quisque uitam suam et futuri desiderio laborat, praesentium taedio.

(De Breu. Vit. 7,8) 9

Such constant worriment is conducive of restlessness and pain.

Calamitosus est animus futuri anxius et ante miserias miser, qui sollicitus est ut ea quibus delectatur ad extremum usque permaneant; nullo enim tempore conquiescet et expectatione uenturi praesentia, quibus frui poterat, amittet.

(Ep. 98,6)

Moreover, it should be obvious that such men ignore the past, in order to turn their full attention upon the brief present and the unknown future.

Clearly, Seneca seems to indicate that the Past is by far the more favorable realm, since it cannot be disturbed by Fate and Fortune, a realm that can, in Wordsworth's terminology, with ease and free will be «recollected in tranquillity ${ }^{10}{ }^{0}$. Yet Seneca nevertheless remarks that man the self-tormentor manages even to disturb his view of the past:

Ferae pericula quae uident fugiunt, cum̃ effugere, securae sunt: nos et uenturo torquemur et praeterito. Multa bona nostra nobis nocent; timoris enim tormentum memoria reducit, prouidentia anticipat...

Hence, most men seek to obliterate the past. They confer upon hope all of the burden for salvaging the future. But there is little possibility for their reformation.

Hoc nos pessimos facit, quod nemo uitam suam respicit; quid facturi simus cogitamus, et id raro, quid fecerimus non cogitamus; atqui consilium futuri ex praeterito uenit.

9 Vid. Ep. 101,9: ...ille enim ex futuro suspenditur cui inritum est praesens.

10 Vid. Ep. 98,11; 99,4-5; Ad Polyb. 10,2-3; De Benef. VI 2,2. 
In short, only the wise man assesses his past, and assesses it with an eye to improving his future. The man who closes his mind to his past renounces learning and experience together. Samuel Johnson avowed that

The present state of things is the consequence of the former, and it is natural to inquire what were the sources of the good that we enjoy, or of the evil that we suffer. If we act only for ourselves, to neglect the study of history is not prudent: if we are entrusted with the care of others, it is not just. Ignorance, when it is voluntary, is criminal; and he may properly be charged with evil who refused to learn how he might prevent it ${ }^{11}$.

Seneca would firmly agree; for one who renounces the past denies causal relationships, repudiates debts, abolishes self-continuity.

Quomodo gratus esse quisquam aduersus beneficia potest, qui omnem uitam suam transilit praesentium totus ac futurorum? Memoria gratum facit; memoriae minimum tribuit, quisquis spei plurimum.

(De Benef. III 4,2)

Yet, above all, Seneca recognizes that virtually all men are caught in such a paradoxical condition; they all suffer from time's dominion, and lack the basic self-sufficiency and self-control to free themselves. All men find something to lament in the past, discover that the present is evanescent, and permit themselves to yearn for a future that - against all oddsmight be better.

...considera uniuersos: nullius non uita spectat in crastinum. Quid in hoc sit mali quaeris? infinitum. Non enim uiuunt sed uicturi sunt: omnia differunt.

(Ep. 45,12-13)

And perpetual postponement conduces to sheer inactivity and inanition.

Illorum breuissima ac sollicitissima aetas est qui praeteritorum obliuiscuntur, praesentia neglegunt, de futuro timent: cum ad extrema uenerunt, sero intellegunt miseri tam diu se, dum nihil agunt, occupatos fuisse.

(De Breu. Vit. 16,1) 12

\footnotetext{
11 Chap. 30 of Samuel Johnson, The History of Rasselas Prince of Abyssinia (1759), ed. Gwin J. Kolb, New York 1962, p. 65.

${ }_{12}$ Cf. Johnson, Rasselas, p. 64: "It seems to me... that while you are making the choice of life, you neglect to live».
} 
Elsewhere, Seneca accurately draws attention to the overall general malaise.

Vis scire quid sit quod faciat homines auidos futuri? nemo sibi contigit.

Man is indeed lost to himself, indecipherable, dislocated: but the future certainly will not guarantee his discovery. For miserable man, in all times and in all places, tends to behave in his usual fashion; his identitycrisis will not be resolved. And meanwhile, man's imprisonment in time is virtually a crucifixion:

Fluit tempus et auidissimos sui deserit. Nec quod futurum est meum est, nec quod fuit; in puncto fugientis temporis pendeo...

(N.Q. VI $32,10-11)$

Seneca, particularly in the late years of his life, experiences the unbearable anguish of time's captivity.

Such a sense of dread about time is often attributed to more modern periods. Lewis Mumford notes that, particularly after A. D. 1345 in Europe, as urban society more and more takes form, emphasis falls increasingly upon clocks and "the regular measurement of time». Accompanying such a change is man's growing awareness of time's flight. "When one thinks of time, not as a sequence of experiences, but as a collection of hours, minutes, and seconds", one increasingly finds fear of time on the rise, a perception of it as "an enclosed space»; thereupon, "the habits of adding time and saving time come into existence ${ }^{13}$. And, as we survey the evolution of the modern era, we do encounter more and more regimentation, more and more awareness of time's rapidity. In the most recent centuries, we discern still more the sense of crisis, the feeling of confinement, of alienation, even of madness as a response to our predicament. Gudrun Brangwen in D. H. Lawrence's novel, Women in Love (1920) is driven to feel the ultimate in isolation and trauma:

"Oh God, the wheels within wheels of people, it makes one's head tick like a clock, with a very madness of dead mechanical monotony and meaninglessness. How I hate life, how I hate it...”

The thought of the mechanical succession of day following day, day following day, ad infinitum, was one of the things that made her heart palpitate with a real approach of madness. The terrible bondage of this tick-tack of

13 Technics and Civilization (1934), New York 1963, pp. 12, 17. 
time, this twitching of the hands of the clock, this eternal repetition of hours and days - oh God, it was too awful to contemplate. And there was no escape from it, no escape ${ }^{14}$.

Here is certainly, if there ever were an instance, excruciating existential Angst! And assuredly such feelings of loneliness, separation, and crisis are a dominant feature of contemporary society ${ }^{15}$.

However, it is not merely in Renaissance and modern Europe that one encounters time perceived as fleeting, fragmented, even absurd; for such a conception Ovid the Roman poet expresses when he writes of Tempus edax rerum ${ }^{16}$. Indeed, every major civilization that becomes urban and sophisticated in its maturity apparently is induced to confront historical awareness and consequently comes to comprehend itself as but a trifling moment in the vast maw of rapacious time. Jacqueline de Romilly, in her Time in Greek Tragedy, traces just such an evolution in Fifth-Century Athens, particularly evident in the works of the three great tragic playwrights. Slowly, as we pass from the work of Aeschylus through Sophocles to Euripides, we observe, de Romilly notes, that time loses its theological dimensions, until it climaxes in the distressing Euripidean consciousness of a "broken chronos», and of "uncertain drift» ${ }^{17}$. Much the same development may be understood as taking place in Roman society ${ }^{18}$.

Yet E. R. Dodds has argued that, among Roman writers prior to Marcus Aurelius, there was little sense of the world's insignificance (earth as

14 New York 1950, Chap. 30, pp. 529-30. The nineteenth century's emphasis upon "predictive» time (relying upon exact measurements) led to a general «feeling of fatigue and enervation"; see Ricardo J. Quiñones, "Time and Historical Values in the Literature of the Renaissance», Aspects of Time, ed. C.A. Patrides, Toronto \& Manchester 1976, pp. 38-56, esp. 54. On the Romantic poets' reaction against time-pieces and strict regimentation, consult «The Clockwork Devil», Chap. 10 of Samuel L. Macey's Clocks and the Cosmos: Time in Western Life and Thought, Hamden, Conn. 1980, pp. 203-24.

is Modern man's concept of time and of self tends to stress flux, "fragmentization", disintegration, pessimism; see Hans Meyerhoff, Time in Literature, Berkeley \& Los Angeles 1960, esp. Chap. 3, pp. 85-119. A. A. Mendilow particularly stresses the many ways that rapid change and technological innovation, together with our acute historical sense, have prompted feelings of alienation and instability; consult Chap. 1 , "The Time-Obsession of the Twentieth Century», in his Time and the Novel, New York 1952, pp. 3-11.

16 Metam. XV 234.

17 Ithaca, New York 1968, esp. pp. 120-22, 141.

18 For example, Sara Mack claims that to find an author in the Roman era more concerned with time than Vergil is impossible; one must turn back to the great trio of Greek tragic playwrights at Athens in the Fifth Century to encounter a similar phenomenon (Patterns of Time in Vergil, Hamden, Conn. 1978, p. 3). Horace too, needless to say, is imbued with a sense of time's rapid flight and of the world's continuous decay; see esp. Carm. II 14 and III 6. 
a mere punctum in the universe), of man's alienation, and of time's incredibly rapid flight ${ }^{19}$. Aurelius, Dodds believes, expresses such feelings with unique intensity, revealing society's lassitude, personal malaise, and a decadence that become more and more apparent as one approaches the decline and fall of the Empire. But we might well contend, as this paper has sought to demonstrate, that Seneca too, well before Aurelius's day, displays a keen sense of human crisis and raw sensitivity to time's hapless flight. Admittedly, Seneca follows earlier Stoics in stressing moral action in life; he concurs that only the present is wholly real, and argues that now is the time man must direct himself to act ethically with self-control ${ }^{20}$. But Seneca as well as Aurelius displays very clearly feelings of crisis, Angst, dismay at time's desperate course.

In fact, the inexorable march of humans in time toward death is sharply and lucidly perceived by Seneca as the most gruesome and grotesque parade:

$$
\begin{aligned}
& \text {...properat cursu } \\
& \text { uita citato uolucrique die } \\
& \text { rota praecipitis uertitur anni; } \\
& \text { durae peragunt pensa sorores } \\
& \text { nec sua retro fila reuoluunt. } \\
& \text { at gens hominum flatur rapidis } \\
& \text { obuia fatis incerta sui: } \\
& \text { Stygias ultro quaerimus undas. }
\end{aligned}
$$

(Hercules Furens 178-85)

Here in the Hercules Furens, the Chorus perceives the awful paradox: all is fated in a rapid rush of time to end each mortal's lifetime. It is fated, yet simultaneously, unaccountably, men in their haste also appear to be

19 Pagan and Christian in an Age of Anxiety: Some Aspects of Religious Experience from Marcus Aurelius to Constantine, Cambridge 1965, pp. 7-10, 21-23, 27-29. His obsessive sense of transitoriness and unreality, caused by the flow of time, led Aurelius to "cosmic pessimism" and his view of "fearful instability" in the universe; see J. M. Rist, Stoic Philosophy, Cambridge 1969, pp. 282-88. On the punctum, see Aurelius, Med. 3,$4 ; 6,36 ; 10,17 ; 12,32$. C. S. Lewis, in The Allegory of Love: A Study in Medieval Tradition, New York 1958, pp. 60-69, makes the point that a propensity toward allegory and a sense of one's "divided will" or bellum intestinum are new cultural features in the later Empire, esp. in the era of Augustine (354-430 A.D.); but he also notes a number of such features in the writings of Seneca.

20 Consult $S V F$ II 509, 518; for Stoics, from the time of Chrysippus on, «immediate moral action is important, not duration of time», and their emphasis is upon the present, the appropriate time for one to take action. Vid. Rist (above, n. 19), p. 283. 
rushing of their own volition into the jaws of this fate. The Chorus later condenses this image, rendering it more terrible and clear:

...tibi crescit omne,

et quod occasus uidet et quod ortus.

...: tibi, mors, paramur.

(Hercules Furens 870-72) ${ }^{21}$

In a striking figure, all living creatures are perceived as "growing» like crops for Death; both night and day nourish this produce - and its harvest is its destruction. Such extreme condensation attains poetic force, and may be compared with the powerful opening lines of Tennyson's «Tithonus»:

The woods decay, the woods decay and fall,

The vapors weep their burthen to the ground;

Man comes and tills the field and lies beneath...22

Such thoughts about Time repeatedly move Seneca to speak in terms of dire urgency:

...inpendio uitae uitam instruunt. Cogitationes suas in longum ordinant; maxima porro uitae iactura dilatio est: illa primum quemque extrahit diem, illa eripit praesentia dum ulteriora promittit. Maximum uiuendi inpedimentum est expectatio, quae pendet ex crastino, perdit hodiernum. Quod in manu fortunae positum est disponis, quod in tua dimittis. Quo spectas? quo te extendis? Omnia quae uentura sunt in incerto iacent: protinus uiue.

(De Breu. Vit. 9,1) $)^{23}$

...senectus... obiciat annos inter uana studia consumptos. Tanto magis urgeamus et damna aetatis male exemptae labor sarciat...

(N.Q. III, Praef. 2)

Seneca certainly felt that all men - himself clearly among them - in the contest with time are bound to fall behind, and he desperately wanted to strive to catch up.

Nonetheless, Seneca, like Marcus Aurelius, endured the crisis about Time with as much dignity and control as he could muster. Although man is captive on a "pinpoint» of time, he may still triumph by self-regulation.

21 Cf. Tro. 382-400.

22 Lines 1-3, in Poems of Tennyson, ed. Jerome H. Buckley, Boston 1958, p. 68.

23 Note that, for Seneca, there is n e ve r sufficient time available to us to cope with essentials; hence, the wasting of time infuriates him; see Ep. 49,5. 
You may overcome the fear of natural disasters, and of death itself, and endure, he informs Lucilius,

...si cogitaueris nihil interesse inter exiguum tempus et longum. Horae sunt quas perdimus. Puta dies esse, puta menses, puta annos; perdimus illos nempe perituros. Quid, oro te, refert num perueniam ad illos? Fluit tempus et auidissimos sui deserit. Nec quod futurum est meum est, nec quod fuit; in puncto fugientis temporis pendeo, et magni est modicum fuisse.

$(N . Q$. VI $32,10-11)$

The key word here is modicus; man must prescribe limits for himself, initiate self-control. In a favorite figure of the Stoics, the world is a stage, and each individual the responsible actor:

Nulla uita est non breuis; nam si ad naturam rerum respexeris, etiam $\mathrm{Ne}$ storis et Sattiae breuis est, quae inscribi monumento suo iussit annis se nonaginta nouem uixisse. Vices aliquem gloriari senectute longa: quis illam ferre potuisset si contigisset centesimum implere? Quomodo fabula, sic uita: non quam diu, sed quam bene acta sit, refert.

$(\text { Ep. } 77.20)^{24}$

The philosopher and anyone in quest of wisdom, Seneca frequently repeats, must regard the end (respice finem $)^{25}$; his awareness of the imminence of death renders him more aware of life. He will live each day as if it were his last, mindful of the end ${ }^{26}$, even consciously shaping his life and each of its days into a rounded whole ${ }^{27}$. He will turn to the learned of the past, engaging in lofty studies with past thinkers ${ }^{28}$. In short, he uses all times to a purpose.

Sapientis ergo multum patet uita, non idem illum qui ceteros terminus cludit: solus generis humani legibus soluitur, omnia illi saecula ut deo seruiunt. Transit tempus aliquod, hoc recordatione comprendit; instat, hoc utitur; uenturum est, hoc praecipit. Longam illi uitam facit omnium temporum in unum conlatio.

(De Breu. Vit. 15,5$)^{29}$

\footnotetext{
${ }^{24}$ On the idea (Platonic and earlier) that the world is a stage, which the Stoics were fond of, consult Chap. 1, "The World as Stage», in Thomas B. Stroup's Microcosmos: The Shape of the Elizabethan Play, Lexington, Ky. 1965, pp. 7-36.

25 Ep. 114,27.

26 Ep. 93,6; De Breu. Vit. 7,9.

27 Ep. 101,8; 10.

28 De Breu. Vit. 14-15.

29 See also Ep. 99,5, and cf. Posidonios, cited in Ep. 78,28-29: Vnus dies hominum eruditorum plus patet quam inperitis longissima aetas. Juan Zaragüeta, in «El tiempo
} 
For man alone among the beasts is a reasoning being, sharing this attribute with God. But, whereas God is naturally perfect, man must struggle, through suffering, through practice, through constant study, and through time to perfect his reason and himself ${ }^{30}$. Only continual devotion to study can even begin to lead a man toward that paradoxical position of perfection, where he rivals and even transcends the gods. And such studies are rewarding, Seneca avers. The great man will in some manner win through to a position where he triumphs over time.

Profunda super nos altitudo temporis ueniet, pauca ingenia caput exerent et in idem quandoque silentium abitura obliuioni resistent ac se diu uindicabunt.

(Ep. 21,5)

The striking point for us is that Seneca himself has proven prophetic. Because of Seneca's own keen self-awareness and insight, it is his own head that still endures above the fleet coursings of time's perpetual flood.

Not marble, nor the gilded monuments

Of princes, shall outlive this powerful rhyme;

But you shall shine more bright in these contents

Than unswept stone, besmeared with sluttish time.

When wasteful war shall statues overturn,

And broils root out the work of masonry,

Nor Mars his sword nor war's quick fire shall burn

The living record of your memory ${ }^{31}$.

AnNa Lydia MotTo

JOHN R. CLARK

en Séneca», Estudios sobre Séneca, Madrid 1966, pp. 359-63, stresses Seneca's emphasis on the moral uses of time. Joseph Moreau, "La apreciación del tiempo en Séneca", ibid., pp. 257-61 (and reprinted as "Sénèque et le prix du temps", BAGB, 1969, pp. 119-24) erroneously argues that the wise man is concerned only with the present (vid. p. 259)

30 Ep. 124,13-14; 20.

31 Shakespeare, Sonnet 55, lines 1-8. 